\title{
Kerentanan Masyarakat Kabupaten Karanganyar terhadap Coronavirus Disease-19 (Covid-19)
}

\author{
Dewi Novita Rani ${ }^{1, *}$, Eva Merita Rahmawati ${ }^{1}$, Lucky Safira ${ }^{1}$, Ria Puspitasari ${ }^{1}$, Rizky \\ Nugroho ${ }^{1}$, Safra Arrevi Maya ${ }^{1}$ \\ ${ }^{1}$ Program Studi Pendidikan Geografi, Universitas Muhammadiyah Surakarta, Indonesia \\ Email : *ndewi2855@gmail.com, evameritarahmawati4@gmail.com, savirosacky27@gmail.com, \\ riapuspitasari2222@gmail.com, rizkyhugroho@gmail.com, safraarrevi14@gmail.com.
}

Dikirim : 17 Juli 2020

Diterima: 25 September 2020

\begin{abstract}
Abstrak: Kabupaten Karanganyar, Provinsi Jawa Tengah terletak di jalur lintas provinsi yaitu provinsi jawa tengah dan jawa timur, karena tersebut maka interaksi dan mobilitas manusia terjadi secara intensif. Interaksi dan mobilitas tersebut berpotensi menjadi pemicu penyebaran Coronavirus Disesase 2019 (Covid-19). Tujuan penelitian ini adalah mengetahui kerentanan masyarakat Kabupaten Karanganyar terhadap Covid-19 dan untuk mengetahui hubungan antara parameter kerentanan masyarakat dan jumlah kasus Covid-19 di Karanganyar. Metode yang digunakan dalam penelitian ini adalah metode deskriptif kuantitatif, teknik analisis yang digunakan adalah teknik analisis statistik deskriptif dan analisis korelasi spearman rank. Hasil analisis menunjukkan bahwa 13 dari 17 kecamatan di Kabupaten Karanganyar tergolong rentan sangat tinggi terhadap Covid-19. Namun demikian, hubungan antara tingkat kerentanan wilayah dan jumlah kasus Covid-19 tidak signifikan yang ditunjukkan oleh nilai signifikansi (1-tailed) $0,017<0,05$. Hal itu terjadi karena kondisi kepadatan penduduk, tingkat Pendidikan, serta akses informasi tentang Covid-19 di Kabupaten Karanganyar tergolong tinggi.
\end{abstract}

Kata kunci: Kerentanan, Covid-19, Karanganyar

\begin{abstract}
Karanganyar Regency, Central Java Province is located in the cross-provincial route, namely Central Java and East Java, because of this, human interaction and mobility occur intensively. These interactions and mobility have the potential to trigger the spread of Coronavirus Disease 2019 (Covid-19). The purpose of this study was to determine the vulnerability of the people of Karanganyar Regency to Covid-19 and to determine the relationship between the parameters of community vulnerability and the number of Covid-19 cases in Karanganyar. The method used in this research is a quantitative descriptive method, the analysis technique used is descriptive statistical analysis techniques and Spearman rank correlation analysis. The analysis showed that 13 of the 17 sub-districts in the Karanganyar Regency were classified as very vulnerable to Covid-19. However, the relationship between the level of regional vulnerability and the number of Covid-19 cases was not significant as indicated by the significance value (1-tailed) $0.017<0.05$. This happened because the condition of population density, education level, and access to information about Covid-19 in Karanganyar Regency was relatively high.
\end{abstract}

Keywords: Vulnerability, Covid-19, Karanganyar 


\section{Pendahuluan}

Dunia digemparkan dengan pandemic Covid-19 yang mengakibatkan adanya sindrom pernapasan akut coronavirus 2 (severe acute respiratory syndrome coronavirus 2 ). Virus ini menyerupai SARS dan MERS karena menyerang pada system pernafasan namun coronavirus merupakan virus baru yang ditemukan di Wuhan, Hubei, China pada Tahun 2019 (Setiawan Rifqi, 2020). Sejak ditemukannya virus ini menyebar dengan cepat dan secara luas sehinga mengakibatkan pandemic global yang berlangsung sampai saat ini.

Semakin meluas dan meningkatnya kasus Covid-19 mengakibatkan dampak sosial dan ekonomi yang sangat mempengaruhi kehidupan masyarakat (Hadi, 2020). Jumlah pengangguran meningkat akibat terhenti atau terganggunya kegiatan perekonomian (Hadi, 2020). Kondisi perekonomian perkotaan yang didominasi perekonomian lokal banyak yang dan harus menutup usahanya. Sehingga kembali ke kampung halaman sebagai opsi penyelamatan dalam menghadapi dampak sosial ekonomi dari bencana Covid-19. Opsi kembali ke kampung menjadi permasalahan baru dari daerah asal pemudik, karena banyak kasus baru yang muncul pada daerah asal pemudik.

Dalam Peraturan Kepala Badan Penanggulangan Bencana Nomor 2 Tahun 2002 tentang Pedoman Umum Pengkajian Resiko Bencana menyebutkan Kerentanan adalah suatu komunitas atau masyarakat yang mengarah atau menyebabkan ketidakmampuan dalam menghadapi ancaman bencana((BNPB, 2012). Dalam peraturan tersebut juga dijelaskan bahwa Indonesia tidak hanya rentan terhadap segala bentuk bencana yang berkaitan dengan aspek alam. Juga dengan bencana yang berkaitan dengan teknologi. Tentunya Indonesia harus siap dalam menghadapi pandemik wabah penyakit ini agar jumlah korban ini segera menurun dan segera ditanggulangi.

Awal mula teridentifikasinya Covid-19 pada Tahun 1960 yaitu sebagai flu dengan jumlah pasien yang terkena 500 pasien, identifikasi gangguan tersebut menyerupai flu (Sampurno, Kusumandyoko and Islam, 2020). Mulanya Virus Corona diperlakukan sebagai virus yang tidak mematikan hingga Tahun 2002. Dari adanya peristiwa tersebut dapat diketahui bahwa Virus Corona bukan virus yang stabil, bahkan mampu berkembang menjadi lebih ganas dan berakibatkan kematian.

Wilayah Kabupaten Karanganyar adalah salah satu kabupaten yang ada di Provinsi Jawa Tengah. Secara letak administrasi, Kabupaten Karanganyar mempunyai batas-batas dengan Kabupaten Sragen di sebelah utara, Provinsi Jawa Timur di sebelah timur, Kabupaten Wonogiri dan Kabupaten Sukoharjo di sebelah selatan, dan Kota Surakarta dan Kabupaten Boyolali di sebelah barat (BNPB, 2012). Berdasarkan letak administrasi, menyebabkan Kabupaten Karanganyar menjadi jalur lintas Provinsi yaitu antara Provinsi Jawa Tengah dan Provinsi Jawa Timur. Karena terletak dilintas Provinsi maka interaksi manusia dan kontak langsung antar manusia terjadi secara intensif. Hal ini menyebabkan Kabupaten Karanganyar memiliki tingkat kerentanan lebih tinggi terhadap penyebaran Covid-19.

Analisis kuantitatif terhadap parameter kerentanan masyarakat, semakin tinggi tingkat kerentanan maka tingkat kerentanan semakin tinggi. Parameter yang digunakan untuk analisis ini yaitu; kepadatan penduduk, rasio penduduk usia rentan, rasio penduduk miskin, dan rasio mata pencaharian. Parameter tersebut adalah hasil dari analisis yang bersumber dari parameter kerentanan menurut Perka BNPB No. 2 Tahun 2012 tentang Pengkajian Resiko Bencana. Akibat terbesar dari bencana pandemik Covid-19 sangat mempengaruhi perekonomian di bidang industry pariwisata dan industri lainnya yang bergantung pada mengumpulkan masa dan lalu lintas manusia. 
Oleh karena itu studi ini fokus pada kerentanan Covid-19 pada mayarakat Kabupaten Karanganyar dan menemukenali keterkaitan analisis kuantitatif terhadap parameter kerentanan masyarakat dan kasus Covid-19

\section{Metode Penelitian}

\section{Jenis penelitian}

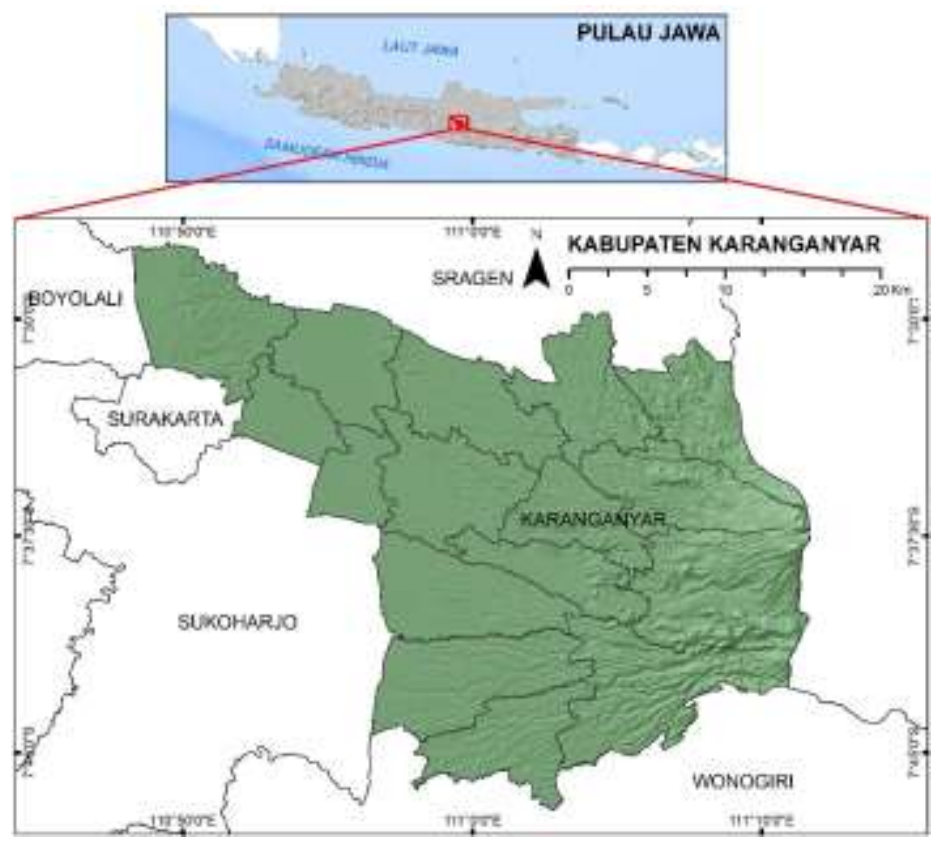

Gambar 1. Kabupaten Karanganyar

Penelitian ini dilakukan dengan menggunakan data sekunder di Kabupaten Karanganyar, Provinsi Jawa Tengah yang berbatasan langsung dengan Kabupaten Sragen di sebelah Utara, Provinsi Jawa Timur di sebelah Timur, Kabupaten Wonogiri dan Kabupaten Sukoharjo di sebelah Selatan serta Kota Surakarta dan Kabupaten Boyolali di sebelah Barat. Secara sudut pandang geografis Kabupaten Karanganyar terletak di antara $110^{\circ} 40^{\prime \prime}-110^{\circ} 70^{\prime \prime}$ BT dan $70^{\circ}$ $28^{\prime \prime}-70^{\circ} 46^{\prime}$ LS (Gambar 1). Peneltian ini merupakan deskriptif kuantitatif, dimana metode dalam penelitian ini merupakan suatu analisis untuk menemukan hasil yang menggunakan data dan berupa angka sebagai alat menganalisis keterangan mengenai apa yang bertujuan untuk diketahui. Penelitian kuantitatif biasanya menggunakan desain eksplanasi, dimana objek penelitianya untuk menguji hubungan antar variabel yang di hipotesiskan_(Mulyadi, 2013).

\section{Pengumpulan data}

Dalam penelitian ini jenis data yang digunakan merupakan data sekunder yang didapatkan melalui buku dan arsip baik yang dipublikasikan maupun tidak dipublikasikan. Penelitian ini menggunakan data yang berasal dari GISDUKCAPIL yaitu data jumlah penduduk tiap kecamatan, data usia penduduk tiap kecamatan, data jumlah penduduk miskin tiap kecamatan, data jumlah tingkat pendidikan tiap kecamatan kemudian data luas wilayah yang berasal dari data inageoportal BIG, dan data jumlah kasus Covid-19 yang di peroleh dari WHO dan KEMENKES. Satuan analisis yang digunakan dalam penelitian ini adalah wilayah administrasi kecamatan. 


\section{Analisis data}

Penelitian ini memerlukan dua teknik analisis data yaitu analisis statistik deskriptif dan analisis korelasi spearman rank. Analisis statistik deskriptif adalah proses analisis statistik yang berfokus pada manajemen, penyajian dan klasifikasi data dengan proses ini, data yang disajikan akan menjadi lebih menarik, lebih mudah dipahami, dan dapat memberikan makna lebih bagi pengguna data. Analisis statistik deskriptif tersebut dikelompokan berdasarkan kelasnya yaitu mulai dari sangat tinggi, tinggi, sedang, rendah, sangat rendah, terdapat berbagai cara untuk mendeskripsikan data yaitu bentuk ukuran numerik dari hasil pengolahan data yaitu dengan menggunakan Microsoft Excel (Junaidi, 2014). Klasifikasi kelas sesuai dengan tingkat dari jumlah, klasifikasi dilakukan dengan menggunakan persamaan simpangan rata-rata dan simpangan baku. Uji statistika yang mengukur keeratan hubungan antara dua variabel disebut analisis korelasi (Nugroho, Akbar and Vusvitasari, 2008). Analisis korelasi spearman rank merupakan suatu pengukura non-parametrik dengan koofisien korelasi yang di simbolkan $r$ (rho), analisis ini memiliki tujuan untuk melihat tingkat keeratan (kekuatan) hubungan dua variabel.

Rumus analisis korelasi spearman

$\mathrm{r}=1-\frac{6 \Sigma d 2}{n\left(n^{2}-1\right)}$

$\mathrm{r} \quad=$ koofisien korelasi spearman

$\Sigma \mathrm{d}^{2}=$ total kuadrat selisih antar rangking

$\mathrm{N}$ = jumlah sampel penelitian

Dasar pengambilan keputusan dalam uji korelasi spearman jika nilai sig <0,05 maka, dapat disimpulkan bahwa terdapat korelasi yang signifikan antara variabel yang dihubungkan. Sebaliknya, jika nilai sig >0,05 maka, dapat disimpulkan bahwa tidak terdapat korelasi yang signifikan antara variabel yang dihubungkan.

Kriteria tingkat hubungan (koofisien korelasi) antar variabel berkisar antara 0,00 sampai 1.00, adapun kriteria penafsiranya yaitu $0,00-0,20$ artinya hampir tidak ada korelasi, $0,21-0,40$ artinya korelasi rendah, 0,41-0,60 artinya korelasi sedang, 0,61-0,80 artinya korelasi tinggi, dan 0,81-1,00 artinya korelasi sempurna.

\section{Hasil dan Pembahasan}

\section{Analisis parameter kerentanan masyarakat}

\section{Kepadatan penduduk}


Parameter yang digunakan pertama untuk menganalisis kerentanan masyarakat adalah parameter kepadatan penduduk dalam analisis kerentanan masyarakat dengan asumsi bahwa semakin padat penduduk maka potensi terpapar virus Covid-19 semakin besar. Karena virus Covid-19 bisa ditularkan secara kontak langsung antara manusia atau tertular melalui barang yang sudah terpapar oleh virus tersebut (Susilo et al., 2020). Dari hasil analisis kepadatan penduduk dapat disimpulkan bahwa bobot kepadatan penduduk tiap kecamatan di Kabupaten Karanganyar bermacam-macam. Namun demikian secara umum kepadatan penduduk dari masing-masing kecamatan tergolong tinggi. Meratanya penyakit berbasis lingkungan dapat diartikan bahwa suatu kondisi patologis berupa kelainan fungsi atau morfologi suatu organ tubuh yang disebabkan oleh interaksi manusia dengan segala sesuatu di sekitarnya yang memiliki potensi penyebaran penyakit. Oleh karena itu, semakin tinggi kepadatan penduduk di suatu kecamatan maka risiko penyebaran virus Covid-19 juga akan semakin tinggi. Perbedaan kepadatan penduduk dipengaruhi karena pertumbuhan wilayah kecamatan yang bervariasi seperti Kecamatan Karanganyar dan Tasikmadu yang merupakan pusat ekonomi dari Kabupaten Karanganyar. Selain itu, Kecamatan Tawangmangu yang merupakan pusat wisata Kabupaten Karanganyar yang memiliki banyak pengunjung wisatawan baik lokal maupun nasional, sehingga Kecamatan Tawangmangu berkembang menjadi pusat pertumbuhan baru.

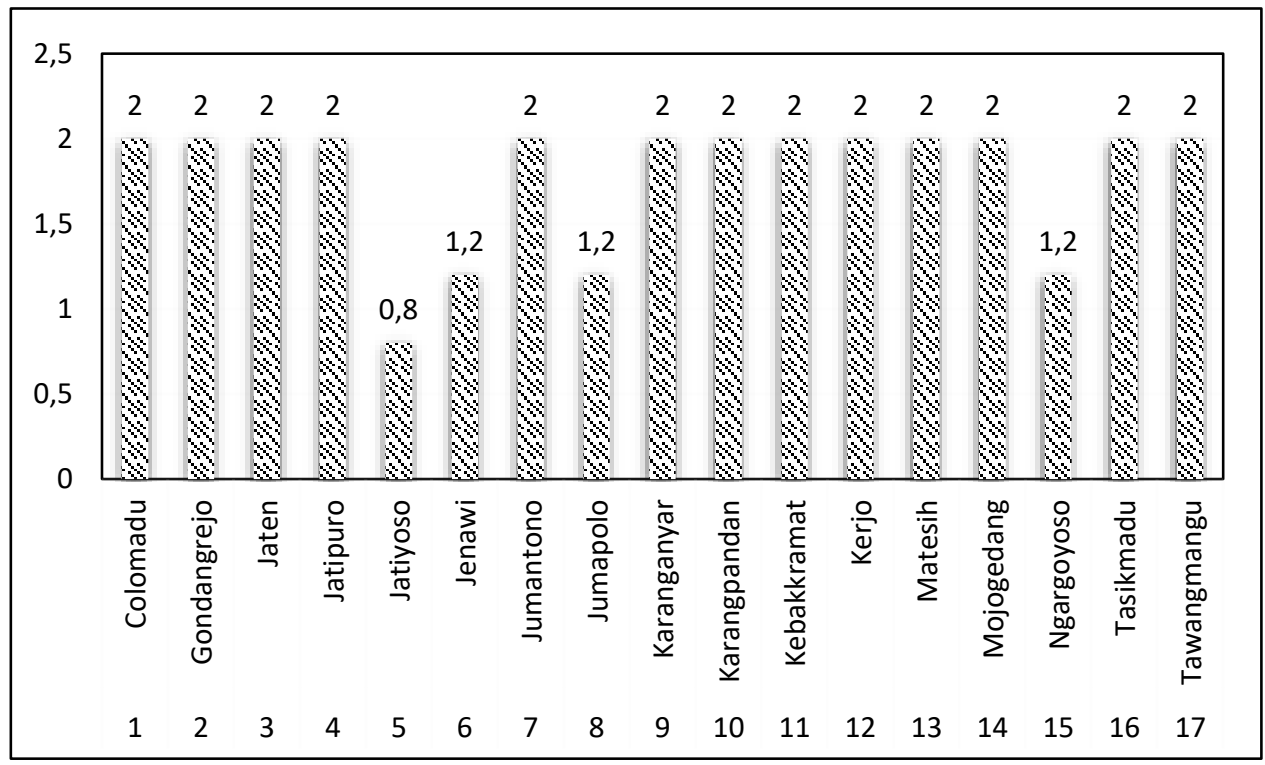

Gambar 2 Kepadatan Penduduk

\section{Rasio penduduk usia rentan}

Rasio penduduk usia rentan merupakan salah satu parameter kerentanan dalam penelitian ini. Rasio penduduk usia rentan dijadikan parameter karena usia juga merupakan salah faktor yang mempengaruhi besarnya risiko seseorang terpapar virus Covid-19. Misalnya semakin tua usia seseorang maka potensi terpapar Covid-19 semakin tinggi karena semakin tua usia seseorang maka imunitasnya cenderung lebih rendah dibandingkan dengan penduduk usia produktif. Dari hasil analisis rasio penduduk usia rentan yaitu umur 50->75 dari masing-masing kecamatan yang berada di Kabupaten Karanganyar semuanya memiliki kelas sangat tinggi. Hal 
tersebut dapat terjadi disebabkan oleh penduduk dari masing-masing kecamatan memiliki komposisi penduduk yang relatif seimbang. Pertumbuhan usia mengakibatkan perubahan terhadap fungsi normal organ tubuh (Scanlon, 2010).

\section{Rasio tingkat pendidikan}

Tingkat pendidikan masyarakat digunakan sebagai salah satu parameter kerentanan dengan pertimbangan bahwa tingkat pendidikan dapat menentukan pola berfikir masyarakat dalam mengambil sikap dalam menghadapi pandemik Covid-19. Pendidikan memiliki hubungan antara peningkatan pengetahuan umum dan pemahaman atas lingkungan kita secara menyeluruh (Scanlon, 2010). Semakin tinggi tingkat pendidikan seseorang maka cara berfikirnya lebih rasional sehingga masyarakat dapat menyerap informasi yang beredar dengan baik. Teori menurut Koencoroningrat yang mengatakan jika tingkat pendidikan seseorang memiliki pengaruh pada pengetahuan, dimana semakin tinggi tingkat pendidikan maka semakin tinggi pula pengetahuan yang akan dimiliki. Dari hasil analisis tingkat pendidikan masyarakat di Kabupaten Karanganyar memiliki kelas rasio tingkat pendidikan yang sama. Seluruh kecamatan di Kabupaten Karanganyar memiliki kelas rasio tingkat pendidikan yang sangat tinggi. Adapun faktor yang mempengaruhi masyarakat Kabupaten Karanganyar memiliki pendidikan dikarenakan tersedianya fasilitas sekolah yang terjangkau dan juga banyaknya masyarakat yang berpenghasilan tinggi. Selain itu, letak Kabupaten Karanganyar yang strategis juga menjadi faktor penunjang tingginya rasio tingkat pendidikan masyarakat Kabupaten Karanganyar.

\section{Rasio jenis mata pencaharian}

Rasio Jenis mata pencaharian masyarakat di Kabupaten Karanganyar sama dengan rasio lainnya yaitu merupakan salah satu parameter kerentanan yang digunakan dalam penelitian ini karena jenis mata pencaharian menentukan tingkat penghasilan dan potensi beraktivitas di luar rumah seperti, Aparatur Pejabat Negara (APN), tenaga pengajar, wiraswasta, petani, peternak, nelayan, ahli agama, pelajar, tenaga kesehatan. Semakin tinggi penghasilan seseorang maka akan dapat mengakses layanan kesehatan dengan baik. Selain itu, jenis mata pencaharian juga mempengaruhi seseorang untuk berinteraksi dengan banyak orang, misalkan seorang pedagang di pasar yang berinteraksi dengan banyak orang dipasar cenderung memiliki risiko yang tinggi terpapar Covid-19 dibandingkan dengan seseorang yang memiliki pekerjaan dengan di dalam ruangan seperti pegawai negeri sipil. Dari hasil analisis jenis mata pencaharian masyarakat di Kabupaten Karanganyar di masing-masing kecamatan memiliki jenis mata pencarain yang relatif sama dan kebanyakan penduduknya memiliki pekerjaan dibandingkan dengan yang tidak memiliki pekerjaan.

\section{Rasio tingkat kesejahteraan}

Masyarakat di Kabupaten Karanganyar cenderung mengurangi aktivitas di luar ruangan karena memiliki sarana penghidupan yang memadai dibandingkan masyarakat dengan kesejahteraan yang lebih rendah. Rasio Tingkat kesejahteraan masyarakat merupakan parameter kerentanan yang dianalisis dalam penelitian ini, tingkat kesejahteraan menentukan kemampuan masyarakat untuk mengakses layanan kesehatan. Dari hasil analisis, tingkat kesejahteraan masyarakat memiliki kelas rasio tingkat kesejahteraan yang hampir sama. Namun hanya Kecamatan Tawangmangu yang belum memiliki kesamaan tingkat kesejahteraan yang sama dengan Kecamatan lainnya di Kabupaten Karanganyar dikarenakan Kecamatan Tawangmangu memiliki lokasi yang berada di ketinggian hingga persebaran perekonomiannya 
belum merata.Tingkat aksesibilitas wilayah juga bisa diukur berdasarkan pada beberapa variabel yaitu ketersediaan jaringan jalan, jumlah alat transportasi, panjang, lebar jalan, dan kualitas jalan (Farida, 2013). Terlepas dari itu bobot tingkat kesejahteraan di Kecamatan Karanganyar tergolong sangat tinggi. Permasalahan utama dalam upaya pengentasan kemiskinan di Indonesia saat ini terkait dengan adanya fakta bahwa pertumbuhan ekonomi tidak tersebar secara merata di seluruh wilayah Indonesia, ini dibuktikan dengan tingginya disparitas pendapatan antar daerah. Selain itu kemiskinan juga merupakan sebuah hubungan sebab akibat (kausalitas melingkar) artinya tingkat kemiskinan yang tinggi terjadi karena rendahnya pendapatan perkapita, pendapatan perkapita yang rendah terjadi karena investasi perkapita yang juga rendah (Lalaun and Siahaya, 2016)

\section{Analisis kerentanan masyarakat dan jumlah kasus covid-19 di Kabupaten Karanganyar}

Kerentanan masyarakat terhadap Covid-19 merupakan tujuan dari penelitian yang hasilnya dapat ditemukan dengan parameter-parameter kerentanan masyarakat yang meliputi kepadatan penduduk,usia rentan, tingkat pendidikan,jenis mata pencaharian dan tingkat kesejahteraan yang ada di Kabupaten Karangayar. Dari hasil analisis parameter kerentanan masyarakat terhadap Covid-19 di Kabupaten Karanganyar dapat disimpulkan bahwa tingkat kerentanan masyarakatnya di masing-masing kecamatan mempunyai tingkat kerentanan yang berbedabeda namun keseluruhannya cenderung sangat tinggi. Kecamatan Jatiyoso tidak tergolong sangat tinggi namun tergolong tinggi dikarenakan disana masyarakatnya mempunyai tingkat kewaspadaan yang sangat tinggi sehingga masyarakat di Kecamatan Jatiyoso lebih aman daripada kecamatan lainnya yang berada di Kabupaten Karanganyar. Adapun data Covid-19 di Kabupaten Karanganyar yang kami peroleh dari data kemenkes pada tanggal 7 juni 2020 yang mencakup ODP, PDP, Positif, Meninggal dunia, Sembuh, dan Total (Gambar 3).

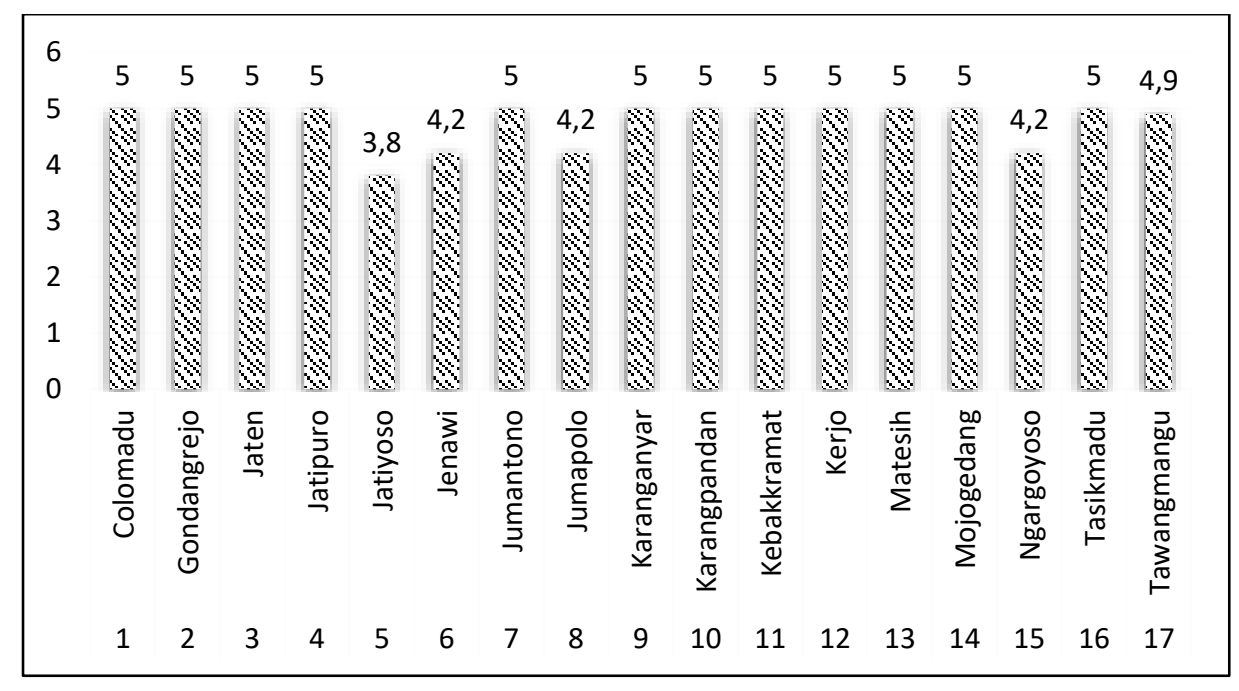

Gambar 3 Analisis kerentanan masyarakat terhadap Covid-19 


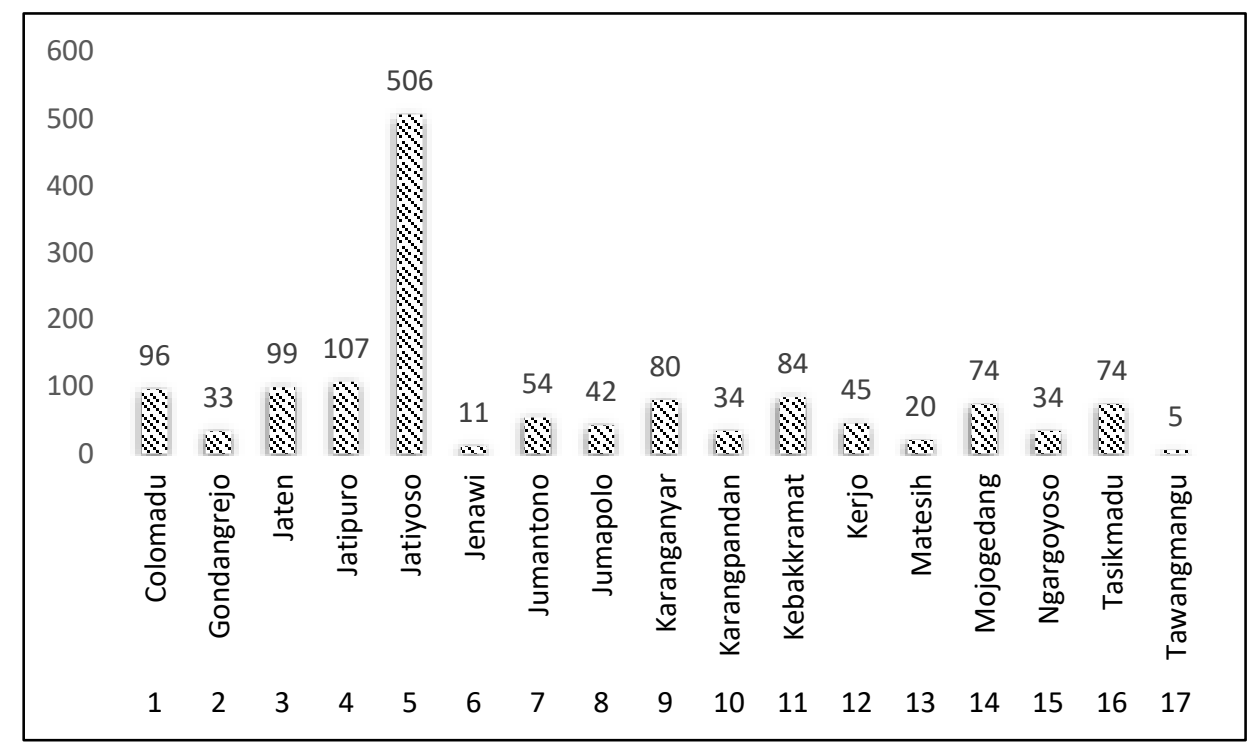

Gambar 4 Jumlah kasus Covid-19 Kabupaten Karangnayar

\section{Hasil uji SPSS model spearman rank}

Hipotesis yang digunakan dalam uji Spss model spearman rank :

Ho : Tidak terdapat hubungan yang signifikan antara kerentanan masyarakat masyarakat dengan kasus covid-19.

Ha : Terdapat hubungan yang sigifikan antara kerentanan masyarakat dengan masyarakat dengan kasus covid-19.

Korelasi Rank Spearman digunakan dengan tujuan menemukan tingkat keeratan (kekuatan) hubungan signifikansi antara masing-masing variable tingkat kerentanan dan kasus pandemic covid-19 yang terjadi di masyarakat. Berdasarkan hasil analisis dan tabel perhitungan menggunakan sofware IBM SPPSS Statistic yang menunjukan angka koofisien korelasi X dan Y. Artinya terdapat tingkat hubungan (korelasi) antara variabel kerentannya adalah sedang. Namun apabila koofisien korelasinya menunjukan angka atau hasil yang negatif maka kerentanan yang terjadi dimasyarakat semakin tinggi maka kasus covid-19 semakin rendah. Akan tetapi nilai signifikansi (1-tiled) $0,017<0,05$ maka ada hubungan yang signifikan antara kerentanan masyarakat dengan kasus Covid-19. Dari hasil uji kolerasi diperoleh kesimpulan adanya hubungan antara kerentanan masyarakat dengan kasus covid-19 yang signifikan, kekuatannya sedang, dan arahnya tidak searah.

Tabel 1. Korelasi akan Signifikan saat berada pada 0.05 level (1-tailed).

\begin{tabular}{llll}
\hline & Sig. & Keputusan & Keterangan \\
\hline $\begin{array}{l}\text { Kerentanan wilayah dan } \\
\text { jumlah kasus Covid-19 }\end{array}$ & 0.05 & Ho ditolak & $\begin{array}{l}\text { Ada hubungan yang signifikan } \\
\text { antara kerentanan masyarakat } \\
\text { dengan kasus Covid-19 }\end{array}$ \\
\hline
\end{tabular}




\section{Kesimpulan}

Berdasarkan dari 17 sampel kecamatan yang diambil dari Kabupaten Karanganyar, pandemic Covid-19 memiliki tingkat kerentanan yang tinggi, pemahaman masyarakat di Kabupaten Karanganyar mengenai virus Covid-19 sangat rendah, masyarakat hanya mengetahui virus Covid-19 itu adalah virus yang menyerang pernafasan dan menyebabkan menular dari satu orang ke orang lainnya melalui percikan air liur atau droplet. Hasil dari 17 sampel tersebut dengan adanya penerapan PSBB di wilayah Kabupaten Karanganyar membuat warga guna meminimalisir penyebaran Covid-19 contoh: tidak boleh adanya kerumunan orang dan menerapkan peraturan protokol kesehatan sesuai anjuran pemerintah dengan baik. Dari data Kabupaten Karanganyar yang telah dianalisis, masyarkat Kabupaten Karanganyar memiliki tingkat kerentanan yang rendah terhadap Covid-19 karena warga Kabupaten Karanganyar memiliki pengetahuan dan tingkat kesadaran yang tinggi terhadap virus Covid-19.

\section{Daftar Rujukan}

BNPB. 2012. Badan Nasional Penanggulangan Bencana 2012. No Title, in Peraturan Kepala Badan Nasional Penanggulangan Bencana.

Farida, U. 2013. Pengaruh Aksesibilitas Terhadap Karakteristik Sosial Ekonomi Masyarakat Pedesaan Kecamatan Bumijawa Kabupaten Tegal. Jurnal Wilayah dan Lingkungan, 1(1), p. 49. doi: 10.14710/jwl.1.1.49-66.

Hadi, S. 2020. Pengurangan Risiko Pandemi Covid-19 Secara Partisipatif: Suatu Tinjauan Ketahanan Nasional terhadap Bencana Pengurangan Risiko Pandemik Covid-19 Secara Partisipatif: Suatu Tinjauan Ketahanan Nasional terhadap Bencana, IV(2), pp. 177190.

Junaidi. 2014. Statistik Deskriptif dengan Microsoft Office Excel, Fakultas Ekonomi dan Bisnis Universitas Jambi: Seri Tutorial Analisis Kuantitatif, pp. 1-8. Available at: http://repository.unja.ac.id/266/1/statistik-deskriptif-excel.pdf.

Lalaun, A. and Siahaya, A. 2016. Dampak Program Pemberdayaan Terhadap Kesejahteraan Masyarakat Di Kecamatan Yaru Kabupaten Maluku Tenggara Barat. Jurnal Ilmiah Ilmu Administrasi Publik, 5(2), p. 73. doi: 10.26858/jiap.v5i2.1759.

Mulyadi, M. 2013. Penelitian Kuantitatif Dan Kualitatif Serta Pemikiran Dasar Menggabungkannya. Jurnal Studi Komunikasi dan Media, 15(1), p. 128. doi: 10.31445/jskm.2011.150106.

Nugroho, S., Akbar, S. and Vusvitasari, R. 2008. Kajian Hubungan Koefisien Korelasi Pearson $(r)$, Spearman-rho $(\rho)$, Kendall-Tau $(\tau)$, Gamma $(G)$, dan Somers ( yx d). Jurnal Gradien, 4(2), pp. 372-381.

Sampurno, M. B. T., Kusumandyoko, T. C. and Islam, M. A. 2020. Budaya Media Sosial, Edukasi Masyarakat, dan Pandemi COVID-19. SALAM: Jurnal Sosial dan Budaya Syari, 7(5). doi: 10.15408/sjsbs.v7i5.15210.

Scanlon, P. H. 2010. Diabetic Retinopathy. Textbook of Diabetes: Fourth Edition, 5(1), pp. 
575-598. doi: 10.1002/9781444324808.ch36.

Setiawan Rifqi, A. 2020. Lembar Kegiatan Literasi Saintik untuk Pembelajaran Jarak Jauh Topik Penyakit Coronavirus 2019 (COVID-19). Jurnal Ilmu Pendidikan, 2(1), pp. 28-37.

Susilo, A. et al. 2020. Coronavirus Disease 2019: Tinjauan Literatur Terkini. Jurnal Penyakit Dalam Indonesia, 7(1), p. 45. doi: 10.7454/jpdi.v7i1.415. 